\title{
Correction to: Spatiotemporal variability of vegetation due to drought dynamics (2012-2017): a case study of the Upper Paraíba River basin, Brazil
}

\author{
Glauciene Justino Ferreira da Silva ${ }^{1}$ (D) . Nádja Melo de Oliveira ${ }^{1}$ (D) . \\ Celso Augusto Guimarães Santos ${ }^{2}$ (D) $\cdot$ Richarde Marques da Silva ${ }^{3}$ (iD
}

Published online: 18 May 2020

(c) Springer Nature B.V. 2020

\section{Correction to: Natural Hazards https://doi.org/10.1007/s11069-020-03940-x}

This correction stands to support the updating of the original article for changing the name Glauciene Justino Ferreira to Glauciene Justino Ferreira da Silva. The author group and the publisher ask the name to be noted as Glauciene Justino Ferreira da Silva and not the former. The original article has been corrected.

Publisher's Note Springer Nature remains neutral with regard to jurisdictional claims in published maps and institutional affiliations.

The original article can be found online at https://doi.org/10.1007/s11069-020-03940-x.

Celso Augusto Guimarães Santos

celso@ct.ufpb.br

1 Postgraduate Program, Civil and Environmental Engineering/CT/UFPB, Federal University of Paraíba, João Pessoa, PB 58051-900, Brazil

2 Department of Civil and Environmental Engineering, Federal University of Paraíba, João Pessoa, PB 58051-900, Brazil

3 Department of Geosciences, Federal University of Paraíba, João Pessoa, PB 58051-900, Brazil 